\title{
耐震補強された鋼製橋脚の地震後の被災度判定 に係る基礎データ収集のための実験的研究
}

\author{
嶋口 儀之 1 ・鈴木 $\quad$ 森晶 2 ・澤田 敏幸 3 ・田端 宜昌 4 \\ 1正会員 修 (工) 愛知工業大学 耐震実験センター（干470-0392 豊田市八草町八千草1247） \\ E-mail: y_shimaguchi@aitech.ac.jp \\ 2 正会員 博 (工）愛知工業大学教授 工学部土木工学科（テ470-0392 豊田市八草町八千草1247） \\ E-mail: suzuki-moriaki@aitech. ac. jp \\ 3一般財団法人 名古屋高速道路協会（干457-0074 名古屋市南区本地通6-1-1） \\ 4一般財団法人 名古屋高速道路協会（干457-0074 名古屋市南区本地通6-1-1）
}

\begin{abstract}
鋼製橋脚は都市内高速道路などに多用されているが，これらの構造物は震災後の緊急輸送道路として位 置つけりられており, 発災後の速やかな機能確保が求められる. 高速道路の早期の機能確保および大規模な 余震等への対策のためには，発災後の初動点検において迅速に被災度判定を行うことが非常に重要である。 本研究では，耐震補強された矩形断面鋼製橋脚を対象として，震災後の初動点検における判定基準，点検 着目部位および点検方法の策定のための基礎的データを得ることを目的として，縮小モデルを用いた静的 繰り返し載荷を行った。而震補強後の橋脚の基本的な耐震性能を確認し, 損傷発生部位および変形量など を計測することで，損傷状況と残留耐力の関係について示した.
\end{abstract}

Key Words : steel bridge pier, seismic retrofit, damage level, seismic performance

\section{1. はじめに}

鋼製橋脚は市街地の高速道路などの公共構造物に多用 されている.これらの構造物は地震により一部の橋脚が 損傷を受けると，構造物全体の機能損失につながる．高 速道路は震災後の緊急輸送道路として位置づけられてお り，発災後の速やかな機能確保が求められる。 また，本 震後に発生が予想される余震および連動地震への対策の ためにも，地震後の初動点検などにおいて，被災状況を 早期に判定することが重要である.

平成 7 年の兵庫県南部地震による被害を受け，鋼製橋 脚を含む土木構造物の耐震性能の向上のための研究が進 められ，耐震設計基準が改定されてきた ${ }^{122)}$. また，旧 基準で設計され，新しい設計基準を満足しない既存鋼製 橋脚についても而震補強が行われてきた ${ }^{3)}$. しかし, 現 行の而震設計基準においても，地震後に橋脚が無損傷で あることを保証するものではなく，道路橋示方書(以下， 道示)においては, 橋脚に要求される而震性能に加え, 地震後の修復性についても言及されている ${ }^{4)}$. しかしな がら，損傷を受けた鋼製橋脚の具体的な修復方法に関し ては規定されておらず，損傷度の判定基淮および修復方 法に関しては，研究事例が極めて少ないのが現状である.
鋼製橋脚の被災度の判定方法については，既往の研究 において橋脚の最大応答水平変位および残留水平変位に より分類する手法が提案されている ${ }^{2}$. し しかし, 最大応 答水平変位による判定は, 地震応答解析等により最大応 答水平変位を求める必要があり, 初動点検などにより確 認することはできないため，早期の対応には向かない． また，残留変位については，地震動の特性によって大き く異なる，例えば，大きな残留変位がない場合にも，繰 り返し荷重により局部的な損傷が生じることが考えられ るが，現在のところ鋼製橋脚の局部的な損傷状況から， 橋脚の残存耐力を推定する手法は確立されていない.

これまで筆者らは，損傷した鋼製橋脚に対する修復方 法についての検討を行ってきたが，実際の橋脚の損傷状 況から残存耐力を推定する手法についての検討は十分で はない 5,9. 鋼構造は損傷後の修復に関する自由度が高 く，修復方法の決定を迅速に行うことができれば，被災 後早期に対応することが可能であると考えられる，その ため, 発災後の初動点検における被災度の判定, 通行規 制の判断および応急処置の要否といったトリアージのた めの各種判定基準の策定が必要である.

本研究では，而震補強された矩形断面鋼製橋脚を対象 として, 発災後の初動点検における判定基準, 点検着目 
部位および点検方法の策定のための基礎的データを得る ことを目的とする．而震補強された矩形断面鋼製橋脚の 縮小モデルを用いて静的繰り返し載荷を行い, 補強後の 橋脚の而震性能を確認し，損傷発生部位および変形量な どを計測し，損傷状況と残留耐力の関係について検討す る.

\section{2. 研究概要}

\section{(1) 実験供試体}

図-1 に実橋脚，図-2 に供試体の概要図を示寸，本研 究では, 昭和 46 年改定の道示に基づき設計され，その 後, 平成 8 年改定の道示に基づき而震補強が行われた矩 形鋼製橋脚を対象寸る ${ }^{3)}$. 実橋脚は $2500 \mathrm{~mm} \times 2000 \mathrm{~mm}$ の 補剛箱型断面で，中詰コンクリートの追加充填およびボ ルト接合による縦リブ断面積の増加により而震補強が行 われている，供試体は実橋脚の約 $1 / 3$ モデルとし，橋軸 方向載荷および橋軸直角方向載荷について各 2 体の計 4 体製作した。図-2 に示すように, 載荷点高さ $\mathrm{h}$ が $3500 \mathrm{~mm}$ ，断面が $750 \mathrm{~mm} \times 600 \mathrm{~mm}$ で，載荷時に圧縮を受 ける側の板厚は実橋脚と同等のパラメータとなるように 橋軸方向が $8 \mathrm{~mm}$ ，橋軸直角方向が $6 \mathrm{~mm}$ となっている. なお，リブの $\mathrm{T}$ 型補強については供試体製作の都合上， 困難であるため, 実橋脚とパラメータが一致するように 補強部のリブ寸法を調整した. 充填コンクリートは補強 後の実橋脚と同様に基部から 3 段目のダイアフラムまで とし, 呼び強度 $16 \mathrm{~N} / \mathrm{mm}^{2}$ の普通コンクリートを使用し た. また, 表-1 に鋼材の引張試験結果および公称值 $\left(\sigma_{y}=325 \mathrm{~N} / \mathrm{mm}^{2}, \quad E=200 \mathrm{kN} / \mathrm{mm}^{2}\right)$ を基に算出した供試体の各 諸量を示す. 降伏水平荷重 $H_{y}$ および降伏水平変位 $\delta_{y}$ は, 式(1),(2)より求め, 軸力比は実橋脚と同じ值とした。 な お，実橋脚においては橋脚基部に根巻コンクリートが設
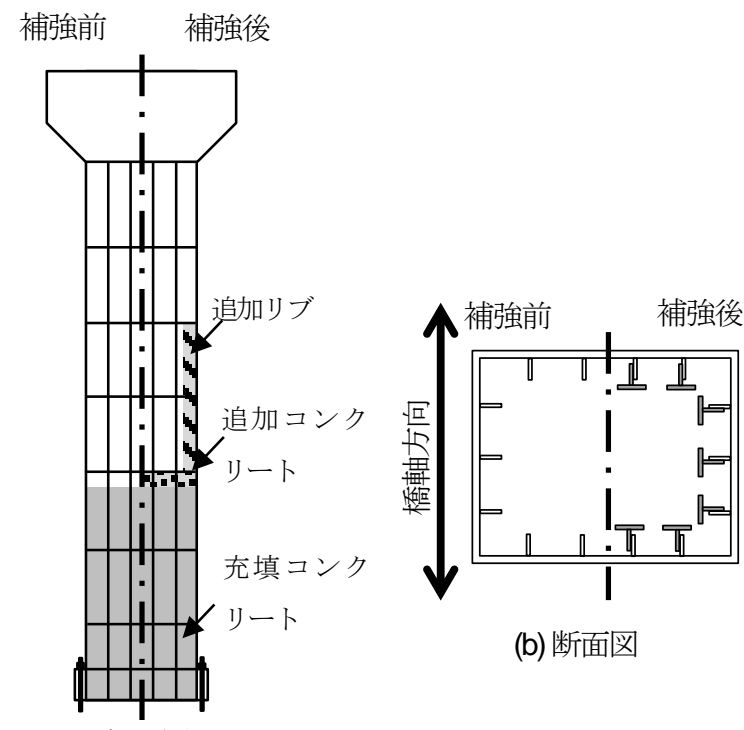

(b) 断面図

図-1 実橋脚概要図

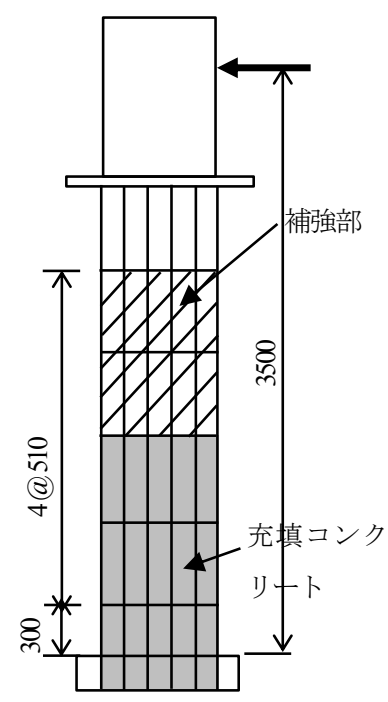

(a) 側面図
(単位 : mm)

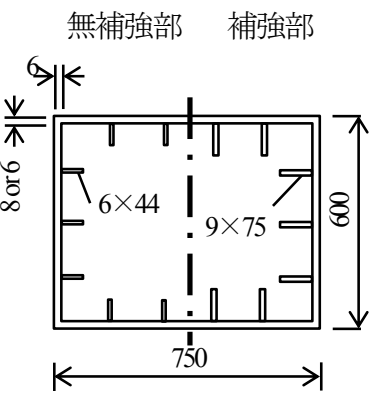

(b) 断面図

図-2 供試体概要図

表-1 実験供試体諸元

\begin{tabular}{|c|c|c|c|c|}
\hline \multirow{2}{*}{ 載荷方向 } & \multicolumn{2}{|c|}{ 橋軸 } & \multicolumn{2}{|c|}{ 橋軸直角 } \\
\hline & 無補強 & 補強部 & 無補強 & 補強部 \\
\hline 鋼種 & \multicolumn{4}{|c|}{ SM490A } \\
\hline 降伏応力 $\sigma_{y} \quad\left(\mathrm{~N} / \mathrm{mm}^{2}\right)$ & \multicolumn{2}{|c|}{412} & \multicolumn{2}{|c|}{376} \\
\hline ヤング率 $E \quad\left(\mathrm{kN} / \mathrm{mm}^{2}\right)$ & \multicolumn{2}{|c|}{211} & \multicolumn{2}{|c|}{202} \\
\hline 幅厚比パラメータ $\mathrm{R}_{\mathrm{R}}$ & \multicolumn{2}{|c|}{0.398} & \multicolumn{2}{|c|}{0.530} \\
\hline 幅厚比パラメータ $\mathrm{R}_{\mathrm{F}}$ & 0.580 & 0.254 & 0.526 & 0.229 \\
\hline 細長比パラメータ $\bar{\lambda}$ & \multicolumn{2}{|c|}{0.358} & \multicolumn{2}{|c|}{0.311} \\
\hline 軸力比 $\mathrm{P} / \mathrm{P}_{\mathrm{y}}$ & \multicolumn{2}{|c|}{0.078} & \multicolumn{2}{|c|}{0.078} \\
\hline 降伏水平荷重 $\mathrm{H}_{\mathrm{y}} \quad(\mathrm{kN})$ & \multicolumn{2}{|c|}{413} & \multicolumn{2}{|c|}{380} \\
\hline 降伏水平変位 $\delta_{\mathrm{y}} \quad(\mathrm{mm})$ & \multicolumn{2}{|c|}{20.7} & \multicolumn{2}{|c|}{16.5} \\
\hline
\end{tabular}


置されているが，本研究では，橋脚基部の補剛板の局部 座屈による損傷の進行状況を詳細に観測するため, 根巻 コンクリートのない供試体を用いて実験を行う.

$$
\begin{aligned}
& H_{y}=\left(\sigma_{y}-\frac{P}{A}\right) \frac{Z}{h} \\
& \delta_{y}=\frac{H_{y} h^{3}}{3 E I}
\end{aligned}
$$

ここで, $\sigma_{y}$ : 降伏応力, $A$ : 断面積, $Z$ : 断面係数, $E$ : ヤング率， $I$ : 断面 2 次モーメントである. なお， $\sigma_{y} お$ よび $E$ は鋼材の公称值を用いた.

\section{(2) 実験方法}

\section{a) 実験載荷装置}

図-3に使用した載荷装置，実験では載荷梁を介して鉛

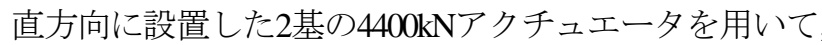
上部構造重量を想定した一定鉛直荷重を載荷する．そし て，水平に設置した1基の4400kNアクチュエータを用い て，地震時の上部構造重量の慣性力を想定した水平繰り 返し載荷を行う。

\section{b) 載荷パターン}

図-4 に載荷パターンを示す．載荷は降伏水平変位 $\delta$, を基準とした漸増変位繰り返し載荷を行う。載荷パター ンは，最大水平荷重に到達し，荷重が低下するまで変位 を漸増させるパターンに加え，最大水平荷重に達しない 範囲での繰り返し載荷による損傷状況を調べるために $4 \delta_{y}$ を 3 サイクル繰り返し載荷するパターンの 2 種類行 う。また， $0.5 \delta_{y}$ 毎に圧縮および引張側の補剛板の変形量 の計測を行う。

\section{(3) 損傷の計測方法}

本研究では，繰り返し載荷時の圧縮および引張側の補 剛板の変形量の計測を行う。図-5に示すように，供試 体にあてたレーザー変位計(株式会社キーエンス製 : IL300)を用いて，局部座屈による x 軸方向の変形量を計測 し，この值を座屈変形量と呼ぶこととする．変位計を $\mathrm{y}$ 軸方向に水平移動させることで座屈変形量を連続的に計 測し，高さ方向は約 $30 \mathrm{~mm}$ 間隔で計測を行う。計測範囲 は図-6に示すように，基部ベースプレートから 1 段目の ダイアフラムまでの間およびコンクリート充填高さの上 下 1 パネル分について行う。なお，クリープ現象による 損傷の進行を考慮し，変形量の計測は，水平荷重を除荷 した状態で行う。

また，図-6 のように座屈変形量の計測と同様の範囲 において，ひずみゲージ(株式会社東京測器研究所製： YEFLA-5)によるひずみの測定を行う.

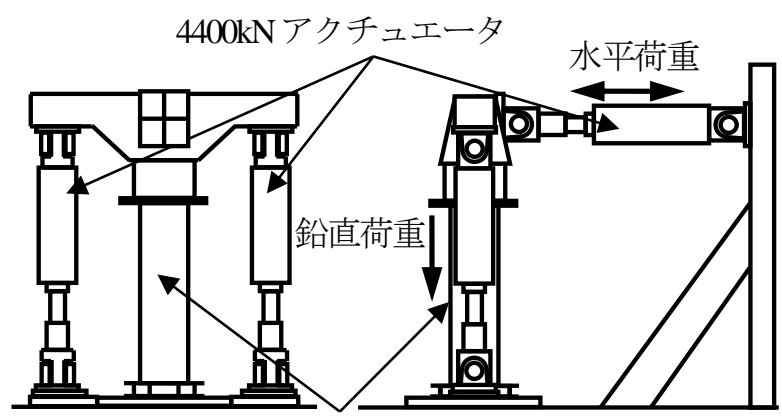

供試体

(a) 正面図

図-3 実験装置概要図

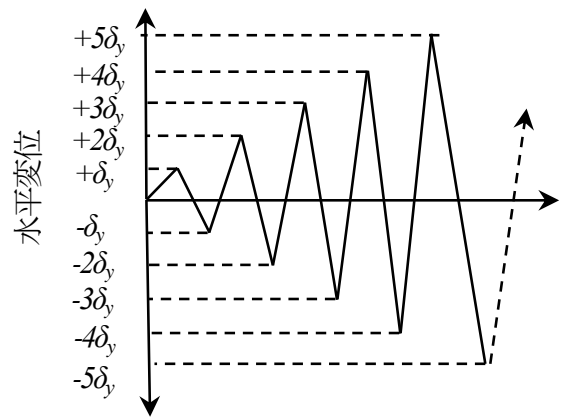

(a) 漸増繰り返し

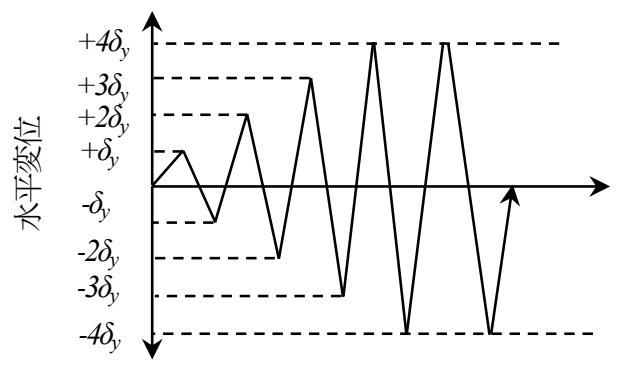

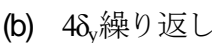

図-4 載荷パターン

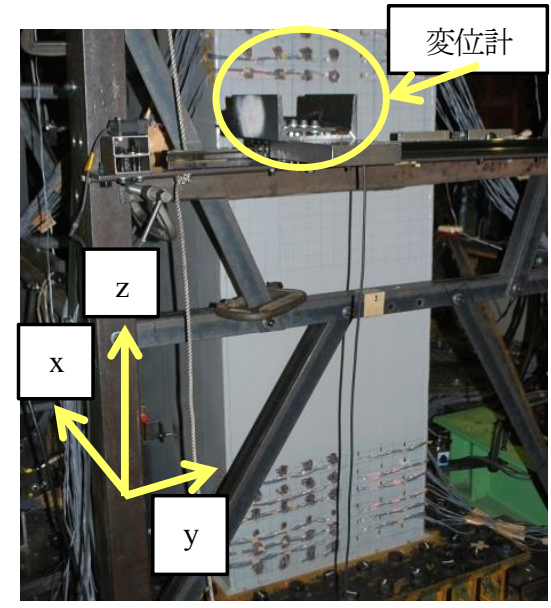

図-5 座屈変形量計測概要 


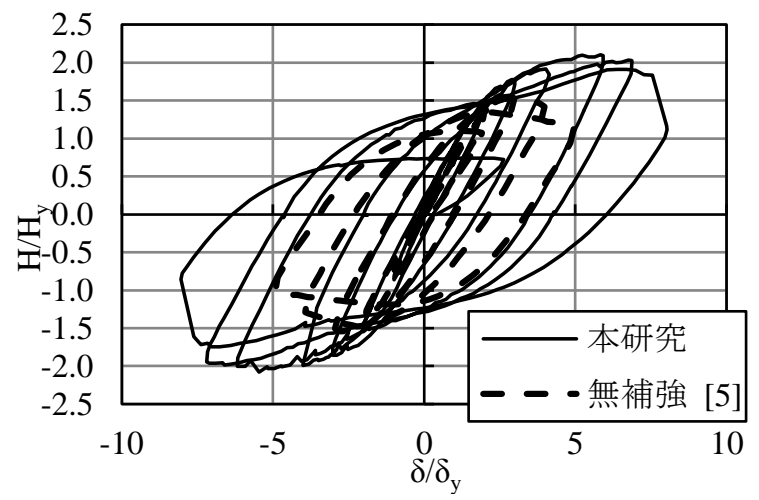

(a) 漸増繰り返し載荷

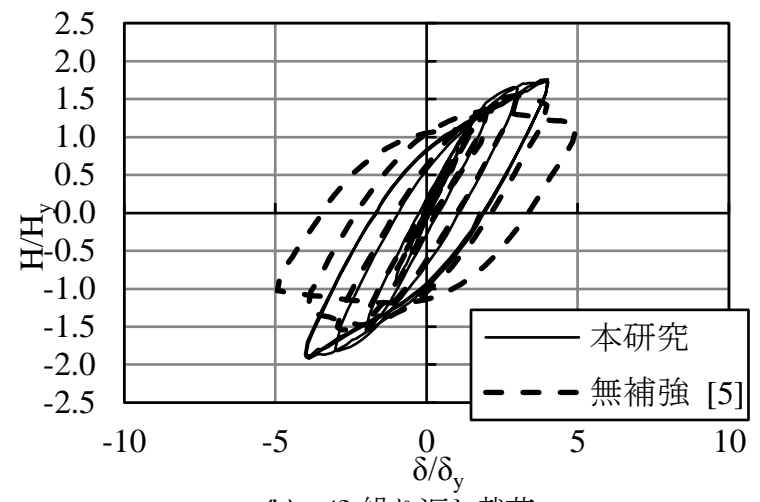

(b) $4 \delta_{\mathrm{y}}$ 繰り返し載荷

図-7 水平荷重-水平変位履歴曲線（橋軸直角方向）

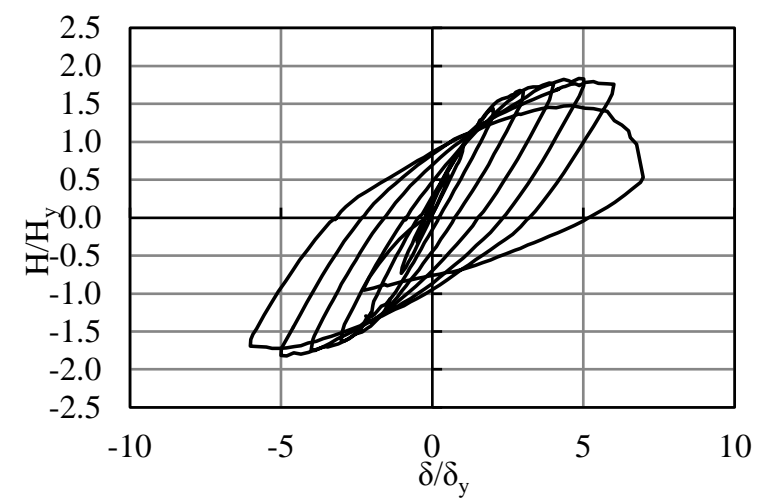

(a) 漸増繰り返し載荷

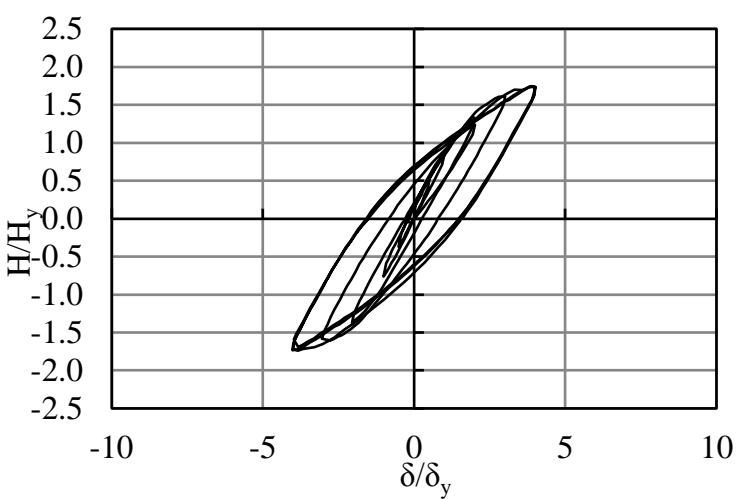

(b) $4 \delta_{\mathrm{y}}$ 繰り返し載荷

図-8 水平荷重-水平変位履歴曲線（橋軸方向）

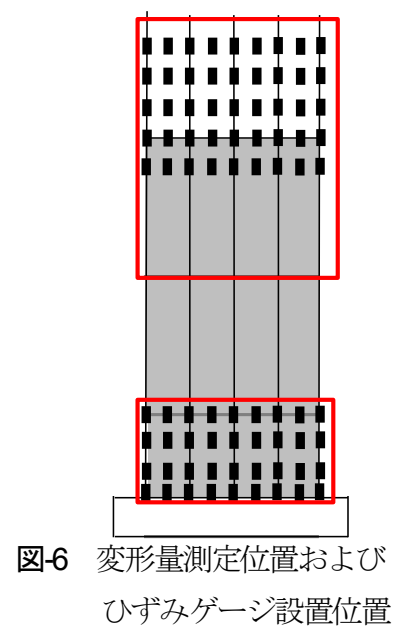

\section{3. 実験結果}

\section{(1) 水平荷重-水平変位関係}

図-7およひ図-8に本研究で得られた水平荷重-水平変位 関係の履歴曲線を示寸. 図の縦軸を降伏水平荷重 $H_{y}$, 横軸を降伏水平変位 $\delta_{y}$ で無次元化している. また，図-7
中の実線は本研究で行った実験結果を示し，破線は無補 強の供試体との比較として, 過去の研究より同程度の座 屈パラメータ $\left(\mathrm{R}_{\mathrm{R}}=0.565\right)$ を有するコンクリート無充填供 試体の実験結果を示す 5 .

図-7(a)より, 橋軸直角方向載荷の場合, 補強後の供試 体は，無補強のものと比較して最大水平荷重が大きく増 加している. また, 無補強のものが $3 \delta_{\mathrm{y}}$ 程度で最大水平 荷重に到達し，その後荷重の低下が見られるのに対し， 補強されたものは $\pm 7 \delta_{y}$ まで耐力の大きな低下は見られず, 変形性能が向上している. 図-7(b)に示した $4 \delta_{y}$ 繰り返し 載荷について見ると, 最初の $4 \delta_{y}$ 到達時と比較して, 3 サイクル目は水平荷重のピーク值が $2.5 \%$ 程度低下して いるが，有意な差はなく，安定した荷重履歴を示した。 また，図-8に示した橋軸方向載荷の場合，漸増繰り返 儿載荷では， $\pm 5 \delta_{y}$ 程度で最大水平荷重に達し， $+7 \delta_{y}$ で大 きく荷重が低下している，また，図-8(b)の4 $4 \delta_{y}$ 繰り返し載 荷の場合，橋軸直角方向と同様に，3 サイクル目におい ても荷重および岡性に大きな低下は見られず安定した履 歴を示した. 


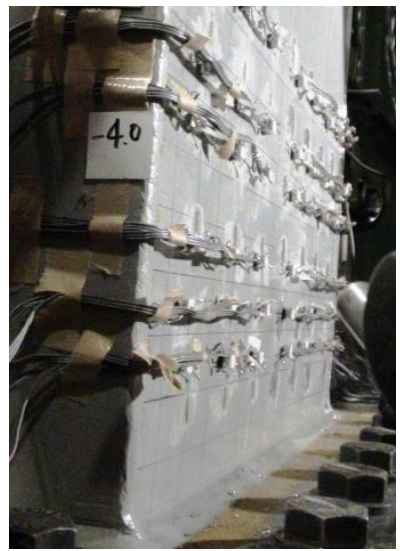

(a) $-4 \delta_{\mathrm{y}}$

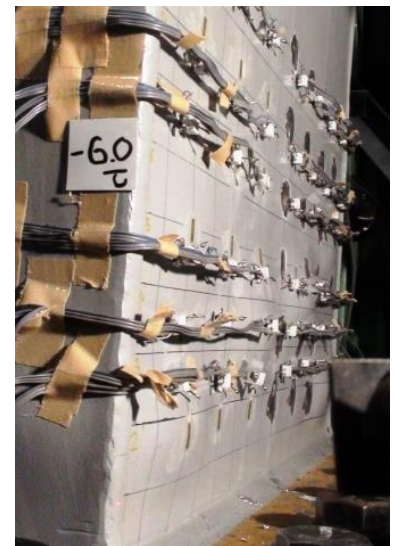

(b) $-6 \delta$

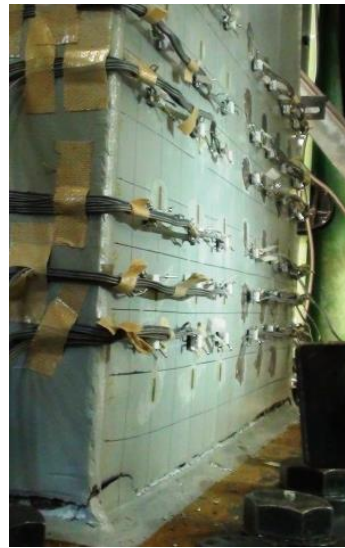

(c) 載荷終了時

図-9 供試体損傷状況 (橋軸直角方向-漸増載荷)

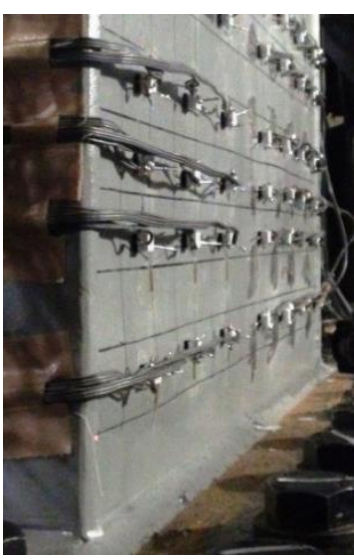

(a) $-4 \delta_{\mathrm{y}} 1$ 回目

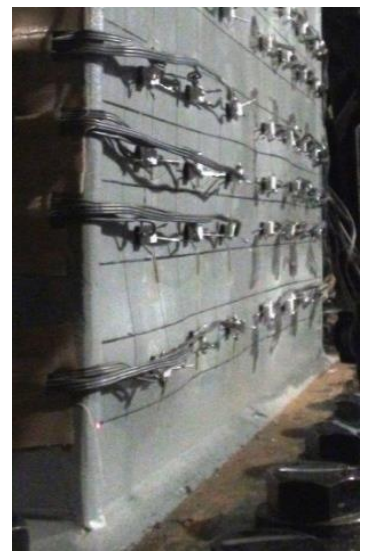

(b) $-4 \delta_{\mathrm{y}} 2$ 回目

図-10 供試体損傷状況 (橋軸直角方向 $4 \delta_{\mathrm{y}}$ 載荷)

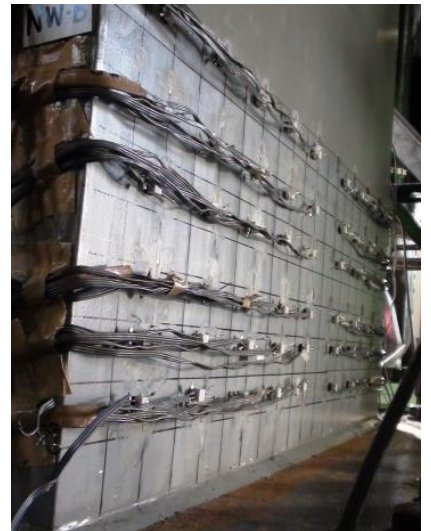

(a) $-5 \delta_{y}$

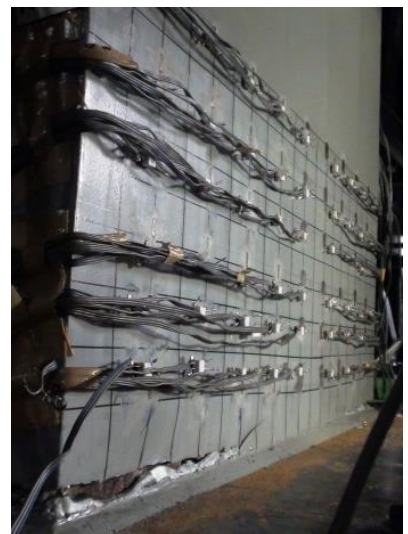

(b) 載荷終了時

図-11 供試体損傷状況 (橋軸方向漸増載荷)

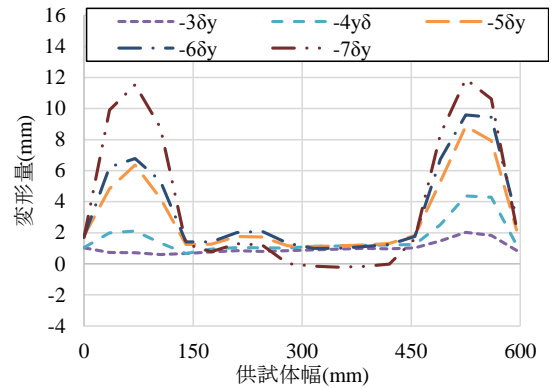

(a) 橋軸直角方向一漸増載荷

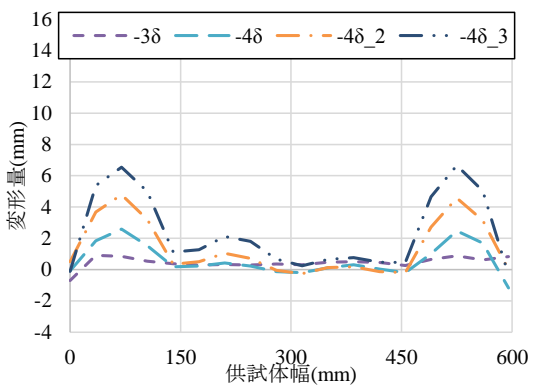

(b) 橋軸直角方向 $4 \delta_{\mathrm{y}}$ 載荷

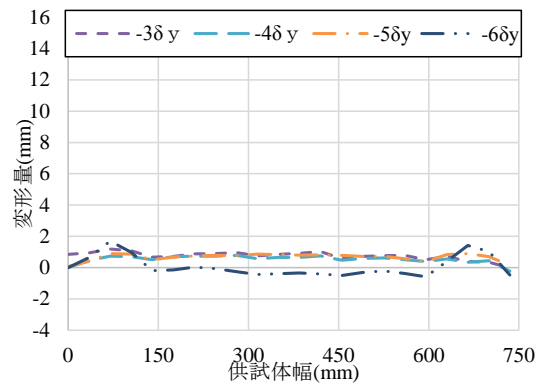

(c) 橋軸方向漸増載荷

図-12 補剛板の座屈変形量 (基部からの高さ $62 \mathrm{~mm}$ )

\section{(2) 供試体損傷状況}

図-9〜図-11 に供試体の損傷状況の例を示す.また, 図-12 には，座屈変形量として，各サイクルにおける補 剛板の局部座屈部の面外方向の変形量の測定結果の一部 を示す. 図-12の縦軸は凸型の変形を正とした場合の座 屈変形量，横軸は補剛板の向かって左端を $0 \mathrm{~mm}$ とした場
合の幅方向(図-5 の y 軸方向)の距離である．橋軸直角方 向載荷においては，4 $\delta_{y}$ 程度から圧縮側の補剛板の基部 付近において目視で確認できる局部座屈が発生し, 繰り 返し載荷毎に座屈が進行した，座屈はすべて縦リブが節 となるような座屈モードとなった．また，7 $\delta_{y}$ のサイク ルにおいて基部にクラックが発生し, 図-9(c)に示すよう 
に，8 $\delta_{y}$ においてクラックが全幅に進展した. 図-12(a)よ り, $4 \delta_{y}$ では最大で $4 \mathrm{~mm}$ 程度, $6 \delta_{y}$ で最大 $10 \mathrm{~mm}$ 程度, $9 \delta_{y}$ で最大 $12 \mathrm{~mm}$ 程度の座屈変形量が確認できた. $4 \delta_{y}$ 繰り返 し載荷においては, 図-12(b)より, 3 度目の $4 \delta_{y}$ で, 最大 で $7 \mathrm{~mm}$ 程度の変形が計測され，目視においては，漸増 載荷における $6 \delta_{y}$ と同程度の損傷を確認した。 最大耐力 に到達しない変位での繰り返し載荷においても, 局部的 な損傷が進行寸るため, このような場合には，最大水平 荷重の低下を招く恐れがあると考えられる.

また，橋軸方向載荷について見ると，図-11(a)より， 最大水平荷重に到達した $5 \delta_{y}$ において, 目視による座屈 変形は確認できなかった。一方で, 引張側のベースプレ 一ト付近の溶接部にクラックが生じた. 図-12(c)に示す ように, 水平荷重が低下し始めた $6 \delta_{y}$ においても変形量 は最大でも $1 \mathrm{~mm}$ 程度であり, クラックのみが進展する 損傷形態となった.

図-12 に示すように，いずれの供試体も橋脚内側への 変形はわずかであり, 外側への座屈変形が大きく進行し ている.これは, 橋脚内部のコンクリートにより, 内側 への変形が拘束されているためである. また, 損傷はコ ンクリート充填部の 1 段目のダイアフラムの高さまでに 生じており, 最終的な破壊はベースプレート付近にクラ ックが生じことによるものであった．ただし，橋軸直角 方向載荷では見られた補剛板の座屈が，橋軸方向載荷に おいては確認できないなど, 挙動に違いが見られた. こ れは, 橋軸直角方向の幅厚比パラメータが橋軸方向より 大きく, 局部座屈が生じやすいためと考えらる.

\section{(3) ひずみ-変形量関係}

ここでは，座屈変形量とひずみ值の関係について検討 する. 図-14 にひずみ值と変形量の関係，図-15 に累積 塑性ひずみと変形量の関係の一部を示す，補岡板に局部 座屈が生じた場合の面外方向の座屈変形量を計測するこ とで, ある程度の範囲でひずみ值を推定することができ れば，橋脚の被災度の判定のために有効な手法であると 思われる，なお，使用したひずみゲージ(YEFLA-5)は， ひずみ限界 $150000 \mu$ ，弾性域での繰り返し計測が可能な ものである. 本研究では大ひずみレベルでの繰り返し載 荷を行うが, 最大で $\pm 20000 \mu$ の範囲で数回程度の繰り返 しである.このため, ひずみ值が載荷状態に追従し，計 測值が安定している範囲においてはある程度の精度があ るとみなし，局部座屈近傍のひずみ值を計測するために 使用した.

図-14 は座屈変形量の測定位置に最も近い箇所のひず みゲージの值の絶対量をプロットしたものである.これ を見ると, 変形量とひずみ值を 1 対 1 で対応させること は難しい. しかし，パネル内に目視で確認できる程度の 変形 $(3 \mathrm{~mm}$ 程度)が生じていれば，おおよそ $10000 \mu$ に達す
るようなひずタ值が生じているという傾向が見られた. 過去の研究結果より 》, 最大水平荷重に達寸る程度の履 歴を受けた場合には $10000 \mu$ を超える程度のひずみが生 じていると推定されていることから, 点検時の判断材料 となる可能性があると考えられる.

また，図-15に示した累積塑性ひずみは，各サイクル の塑性ひずみを随時足し合わせたものである. 図-13に 示寸ように, 水平荷重が 0 となった点から, 次に 0 とな るまでのひずみの絶対量を図中に示した式のように加算 することで算出する，累積塑性ひずみについては，橋軸 方向載荷の供試体と比較すると, 橋軸直角方向載荷の供 試体において, より変形量との関連が見られる結果とな った. これは, 橋軸直角方向の供試体がより, 幅厚比パ ラメータが大きいためだと考えられる. 今回対象とした 橋脚は, 昭和 46 年に規定された古い基準で設計されて おり, 橋軸直角方向については $\mathrm{R}_{R} \geqq 0.5$ の非常に局部座 屈が生じや寸い構造であったことも要因であると考えら れる.

\section{(4) 損傷発生箇所と点検時の着目部位についての検討}

今回対象とした橋脚の損傷個所については，いずれも コンクリート充填部のベースプレート近傍となっており, 実際の点検においても橋脚基部付近を重点的に点検する 必要があると思われる，幅厚比パラメータが大きい橋軸 直角方向については, 補剛板に局部座屈が生じることが 予想され，目視により損傷の確認が可能であると考えら れる. 橋軸方向については, ベースプレート付近でのク ラックが生じるまで，目視で確認できるような損傷がな いため，明確な損傷がない場合についても対策を検討す る必要があると思われる。

また, 本研究では, 橋脚基部の補剛板の損傷状況を詳 細に観測するため, 根巻コンクリートのない供試体を使 用したが，今回の供試体に生じた損傷は，実橋脚におい ては根巻コンクリートに覆われた箇所である.さらに, 根巻コンクリートを設置することで, 補剛板の損傷状況

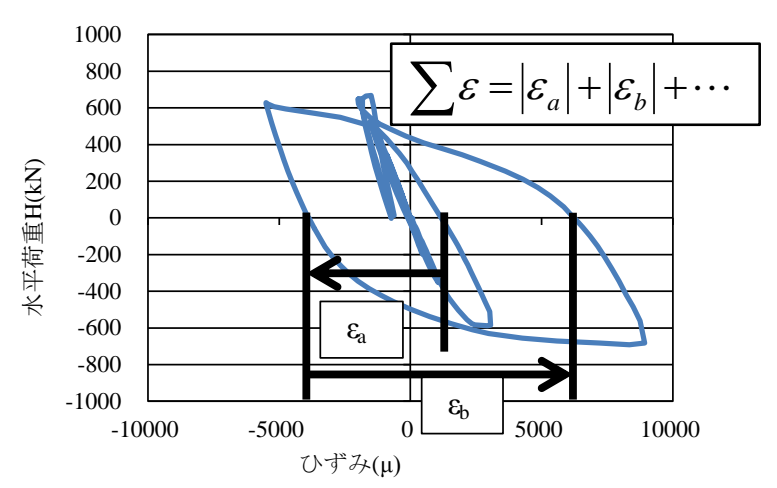

図-13 累積塑性ひずみの算定方法 


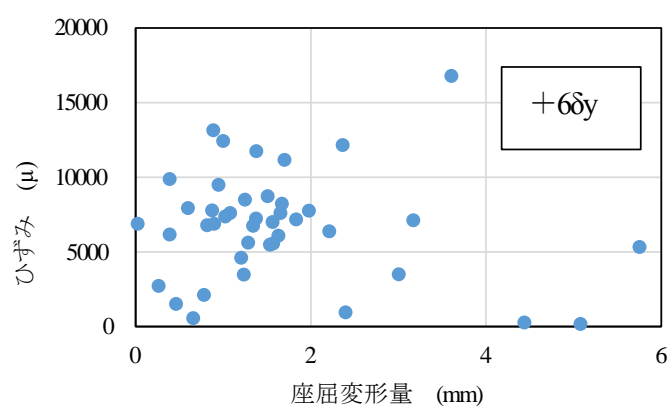

(a) 橋軸直角方向漸増載荷

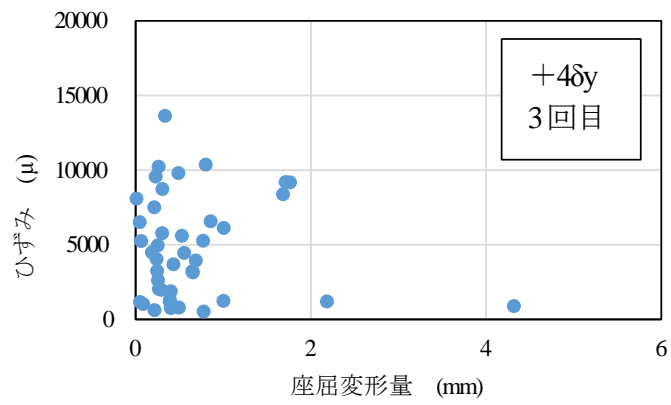

(c) 橋軸直角方向 $-4 \delta_{\mathrm{y}}$ 載荷

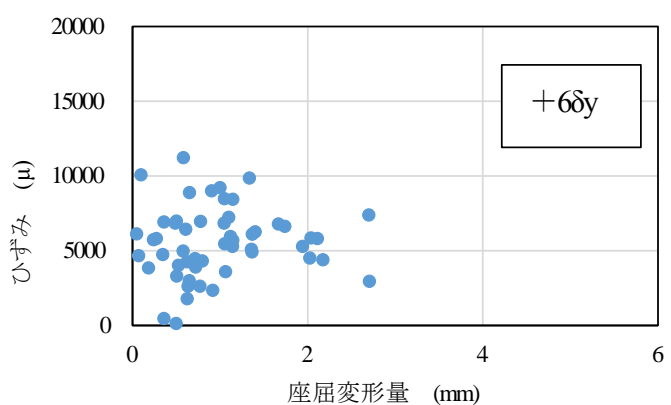

(b) 橋軸方向漸増載荷

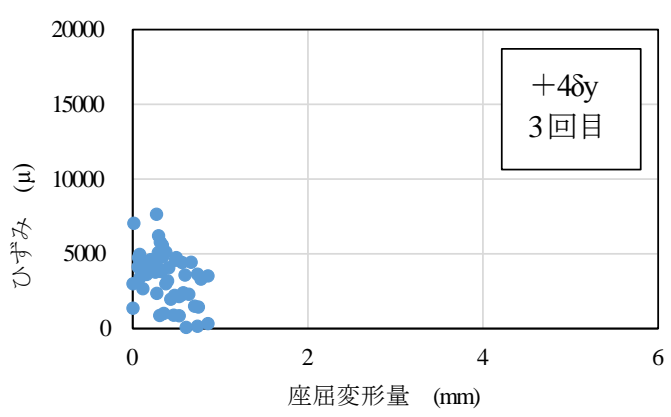

(d) 橋軸方向 $-4 \delta_{\mathrm{y}}$ 載荷

図-14 ひずみ一変形量関係

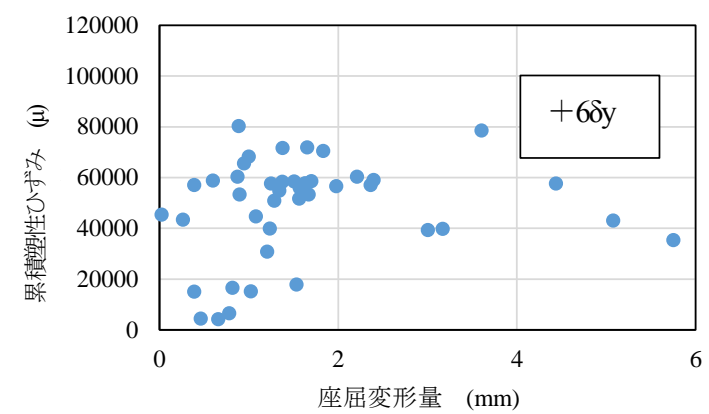

(a) 橋軸直角方向漸増載荷

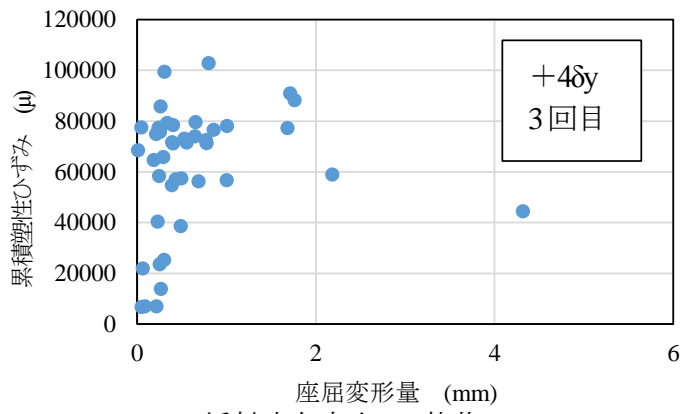

(c) 橋軸直角方向 $-4 \delta$ 載荷

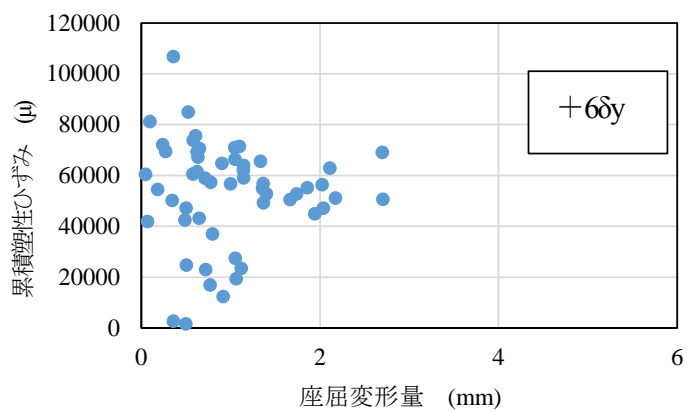

(b) 橋軸方向漸増載荷

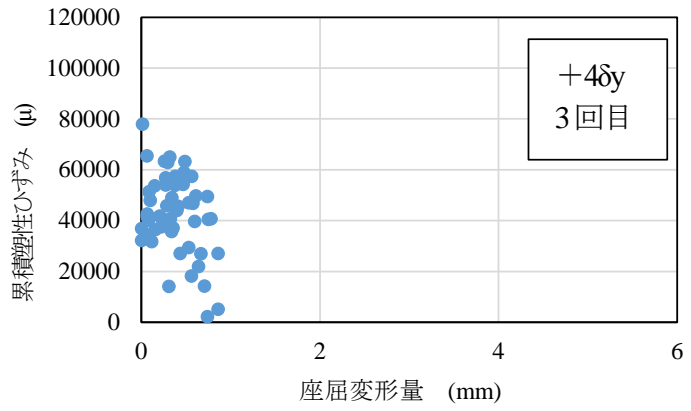

(d) 橋軸方向 $-4 \delta_{\mathrm{y}}$ 載荷

図-15 累積塑性ひずみ一変形量関係

が異なることも考えられる，そのため，根巻コンクリー 卜の有無による, 損傷の発生位置および進行状況の変化 について検討する必要が有る．また，害際の点検におい ては, 根巻コンクリートの損傷および橋脚との剥離の状 況について考慮する必要があると考えられる.

\section{4. まとめ}

本研究では，而震補強された矩形断面鋼製橋脚を対象 として, 発災後の初動点検における判定基準, 点検着目 部位および点検方法の策定のための基礎的データを得る ことを目的として，縮小モデルを用いた静的繰り返し載 荷を行った. 而震補強後の橋脚の基本的な而震性能を確 
認し，損傷発生部位および局部座屈部の変形量とひずみ 值の関係について示した. 以下に本研究で得られた結論 を示す.

1) 耐震補強後の鋼製橋脚の而震性能の向上を確認し, 最終的にはベースプレート付近でのクラックが生 じる破壊形態となることを確認した.

2) 最大水平荷重に達しない範囲での繰り返し載荷に おいても，局部的な損傷が進行しており，最大水 平荷重が低下寸る可能性がある.

3) 橋軸直角方向は $R_{R}$ が比較的大きい場合，橋脚基部 付近に目視で損傷が確認できる局部座屈が生じ, 座屈変形量を測定することで，ひずみ值との関係 から鋼製橋脚の損傷度合を判定するための材料と なり得る.

4) 実際に損傷の点検をする上では，繰り返し載荷時 の補剛板の損傷の進行に対する根巻コンクリート

の有無の影響および根巻コンクリートの損傷状況 ついて明らかにする必要がある.

謝辞 : 本研究は一般社団法人日本鉄鋼連盟の研究助成 (鋼構造研究・教育助成事業)，一般社団法人名古屋高 速道路協会の助成および愛知工業大学而震実験センター
研究経費を使用し，愛知工業大学耐震実験センターにお いて実施した.ここに感謝の意を表す。

参考文献

1)阪神高速道路管理技術センター : 大震災を乗り越えて-震 災復旧工事誌，阪神高速道路公団，1997.9.

2) 土木学会鋼構造新技術小委員会: 鋼構造新技術小委員会 最終報告書（而震設計研究）， 1996.

3) 名古屋高速道路公社 : 名古屋高速道路而震補強工事誌, 2007.8 .

4) (社)日本道路協会: 道路橋示方書・同解説 $\mathrm{V}$ 而震設計編, 2012.3.

5) 嶋口儀之, 鈴木森晶, 太田樹, 青木徹彦：損傷レベルが異 なる矩形断面鋼製橋脚のコンクリート充填修復と而震性能 に関寸る研究，構造工学論文集，Vol.59A，pp.484492，20133.

6)嶋口儀之，鈴木森晶：異なる径厚比を有する円形鋼製橋却 のコンクリート充填修復と而震性能に関する実験的研究, 土木学会論文集 A2(応用力学), Vol.70, No2(応用力学論文集 Vol.17), I _ 565-_ _ 573, 2014.

7) 太田 樹， 鈴木森晶，嶋口儀之 : 異なる損傷度合の円形 断面鋼製橋脚のコンクリート充填修復と而震性能に関す る研究，土木学会論文集 A2(応用力学)，Vol.69，No.2(応用 力学論文集 Vol.16), I_381-390, 2013.9.

(2015.6.23受付)

\title{
AN EXPERIMENTAL STUDY FOR THE BASIC DATA COLLECTION RELATING TO JUDGMENT OF DAMAGE LEVEL FOR RETROFITTING STEEL BRIDGE PIER AFTER EARTHQUAKE
}

\author{
Yoshiyuki SHIMAGUCHI, Moriaki SUZUKI, Toshiyuki SAWADA \\ and Yoshimasa TABATA
}

In this study, we carried out static cyclic loading of the rectangular steel bridge piers. Determination criteria in the initial inspection after the earthquake, is intended to collect the basic data for the development of inspection focused site and inspection methods. We checked the basic seismic performance of retrofitted steel bridge pier, and investigated the relationship of damage and residual strength by measuring the damage occurrence site and the amount of deformation. 